\title{
Determinants of Fan Engagement in Social Media-Based Brand Communities: A Brand Relationship Quality Perspective
}

\author{
Liguo Lou ${ }^{1}$, Yongbing Jiao ${ }^{2}$ and Joon Koh ${ }^{3, *(D)}$ \\ 1 College of Economics and Management, Ningbo University of Technology, 201 Fenghua Road, \\ Ningbo 315211, China; alexlou87@hotmail.com \\ 2 School of Business, Taizhou University, 1139 Shifu Road, Taizhou 318000, China; robynjoy@outlook.com \\ 3 School of Business Administration, Chonnam National University, 77 Yongbong-Ro, Kwang-Ju 61186, Korea \\ * Correspondence: kjoon@chonnam.ac.kr; Tel.: +82-62-530-1459
}

check for

updates

Citation: Lou, L.; Jiao, Y.; Koh, J. Determinants of Fan Engagement in Social Media-Based Brand Communities: A Brand Relationship Quality Perspective. Sustainability 2021, 13, 6117. https://doi.org/ $10.3390 /$ su13116117

Received: 18 April 2021

Accepted: 24 May 2021

Published: 28 May 2021

Publisher's Note: MDPI stays neutral with regard to jurisdictional claims in published maps and institutional affiliations.

Copyright: (c) 2021 by the authors. Licensee MDPI, Basel, Switzerland. This article is an open access article distributed under the terms and conditions of the Creative Commons Attribution (CC BY) license (https:// creativecommons.org/licenses/by/ $4.0 /)$.

\begin{abstract}
This study adopts a brand relationship quality (BRQ) perspective to reveal the reason firms' investments in social media-based brand communities should increase their social relationship marketing performances. An empirical analysis with 234 Facebook users who joined brand communities was conducted to examine the proposed hypotheses, revealing that fan needs fulfillmentsinformation, entertainment, social interaction, and monetary ones-had positive effects on BRQ. Further, BRQ was found to have positive effects on fans' engagement behavioral intentions toward brands, including willingness to buy, member continuance intention, and electronic word of mouth intention. This study contributes to existing research that indicates a new mechanism of BRQ improvement via the social media-based brand community. Implications corresponding to the research findings as well as study limitations and future directions are also addressed.
\end{abstract}

Keywords: social media; brand fan; needs fulfillment; brand relationship quality; fan engagement

\section{Introduction}

For the past few decades, to build and garner consumer-brand relationships has been a core principle for marketing practitioners and researchers because the focus of marketing has been shifting from a transaction-based to a relationship-centered approach [1-3]. Recently, scholars have developed Marketing 4.0 to call for a shift from simply utilizing traditional means to more digital approaches to reach customers and develop relationships with them [4-6]. Social media, as a representative digital tool in Marketing 4.0, plays an extensive role in our daily lives; consequently, brands across the globe are registered with social media platforms to foster relationships with consumers primarily via brand communities [7-9]. A brand community enabled by Facebook, Twitter, or Weibo, for example, is referred to as a social media-based brand community, which is a commonly accessed virtual community currently [10].

Considering the frequently used social media apps on our smart phones, it is evident that we often join a few brand communities on them. Among these brand communities, some act as useful marketing tools that facilitate brands to interact with fans and provide fans various benefits, which, in turn, encourages them to perform online brand-related activities like prosumers [11-13]. Loyal customers having brand attachment even become prosumers who actively create useful contents in their social media-based brand communities, helping other customers for problem solving, ultimately contributing to firm's marketing performance [12]. For instance, Nike and Redbull have invested a lot in their Facebook brand communities and have acquired a considerable number of loyal members who became important actors participating in value co-creation. On the contrary, some brand communities exist only in name, where brand fans lose touch with the host brands and gradually become zombie fans or withdraw from the communities. Undoubtedly, attracting and acquiring brand fans via social media is just the beginning, and managing 
sustainable relationships with the fans and ensuring they are active by nurturing brand communities is a task of top priority, which determines the effectiveness of brand communities $[14,15]$. Previous studies have revealed that a key brand community success factor is fan (member) engagement (e.g., [14,16-18]). Following Pansari and Kumar [19], fan engagement could be defined as fans' different activities in brand communities that influence a brand's performance. To promote fan engagement, firms (brands) endeavor to enhance fan-perceived social presence [11], perceived interactivity [18], and perceived community benefits [17], as well as to provide various useful posts to fans [14] and improve the brand community website quality [13]. Meanwhile, the engaged consumers were found to primarily exhibit high brand loyalty and related behaviors (e.g., [16,17]).

Given the importance of increasing and retaining brand fans, more research efforts are needed to investigate the mechanism of fan engagement in the context of social mediabased brand community. Although some studies explored consumers' motivations behind joining the brand community and engagement with brand (e.g., [14,17]), less attention has been given to the brand as a member of a community that comprises social interpersonal relationships [15]. To address this gap in research, this study adopts the concept of brand relationship quality (BRQ) proposed by Fournier [2] to consider the brand as a "friend" who wants to develop a "personal" relationship with its fans within the brand community. The BRQ is a customer-based indicator of the strength and depth of the customer-brand relationship, which results from brand marketing activities and then results in customer reciprocal actions $[2,3,8,20,21]$. Further, according to Nyffenegger et al. [3], a key challenge in enhancing BRQ is competently fulfilling the brand promise made to customers. However, limited research exists on investigating what the brand promises are in the social mediabased brand community context. Moreover, research that explores whether the host brand keeps its promises could lead to BRQ is scant. Therefore, the first goal of this study is to adopt the needs theory to explore the effects of fan needs fulfillment on BRQ, since the extent to which the host brand keeps its promises is evaluated by fans whose needs are well satisfied or not. Then, based on the BRQ theory, this study discusses the relationships between the $B R Q$ and fan engagement behaviors, which addresses the important mediator role of $B R Q$, achieving the second research goal.

This study contributes to the literature via showing empirical evidence that the host brands who help fans fulfill needs could develop strong and deep interpersonal relationships with fans, which consequently improves the effectiveness of social media-based brand community strategy via enhancing fan engagement. This paper consists of seven sections. Section 2 presents literature review regarding the BRQ and customer engagement. Section 3 develops research hypotheses corresponding to the research goals. Sections 4 and 5 present research method and hypotheses test results. Finally, Sections 6 and 7 discuss research findings, draws certain theoretical and managerial implications, and recommends future research directions.

\section{Literature Review}

\subsection{Brand Relationship Quality}

Fournier [2] used the metaphor of interpersonal relationships to theoretically construct a model reflecting the relationships between brands and consumers. The following were the core statements: (1) a brand can be a partner of consumers, suggesting it could interact with consumers by completing many brand behaviors; (2) relationships built through interactions between the brand and consumers are purposive and reciprocal, suggesting that the brand helping consumers fulfill their needs could elicit consumers' reciprocal responses; and (3) relationships that could be developed in many ways are dynamic, in which the BRQ concept is suggested as a diagnostic instrument to evaluate the relationship strength and depth. The BRQ construct was developed based on the consensus that relationship quality is the essence of customer relationship management (CRM) [21] and was considered as an alternative to brand loyalty, which is one of the most frequently used indicators regarding the measurement of the strength of consumer-brand relationships [2,22]. 
Further, Fournier [2] proposed that the BRQ is an integrated multifaceted construct, consisting of love/passion, self-connection, intimacy, interdependence, commitment, and brand partner quality. Based on Fournier [2], some prior studies conceptualize the BRQ as a multidimensional construct including passionate attachment, love, self-connection, nostalgic connection, intimacy, brand partner quality, and personal commitment [20], or trust, commitment, and satisfaction [23], or the hot BRQ (i.e., commitment, intimacy, and passion) and cold BRQ (i.e., satisfaction and trust) [3,24], or trust and satisfaction [21]. Meanwhile, the BRQ construct could be also operationalized as a unidimensional construct (e.g., $[8,10,25])$.

Based on reviewing the prior studies abovementioned, this study finds that (1) no consensus exists regarding the dimension and measurement of the BRQ, as Athanasopoulou [26] suggested; (2) the BRQ is the foundation of subsequent related constructs such as brand love $[27,28]$, brand attachment $[29,30]$, brand passion [31], and brand addiction [32]; (3) such similar concepts as brand love, brand attachment, brand passion, and brand addiction may suffer from a conceptual overlap. The discrepancy in identifying the dimension of the BRQ sometimes leads researchers to be perplexed about how to operationalize the BRQ. Moreover, Bengtsson [33] proposed that "some of the brand relationship quality constructs are less capable of representing the way consumers relate to their brands" (p. 157). To deal with these problems, this study tries to operationalize the $\mathrm{BRQ}$ as a unidimensional construct following Algesheimer et al. [25] and Gómez et al. [29]. Based on Algesheimer et al. [25], this study defines the BRQ as the degree to which brand fans view the brand as a satisfactory partner in an ongoing relationship. This definition emphasizes the customer-centric marketing approach which states that a brand should endeavor to satisfy fans' needs.

In the social media era, previous research applies the BRQ theory in the brand community context, revealing the impacts of firms' investments in customer relationships on customers' psychological and behavioral responses. For instance, firms could utilize the Facebook brand communities to build consumer-brand relationships where experiential and functional benefits could enhance the BRQ, leading to positive word of mouth (WOM) $[8,23]$. Further, firms' brand community activities could enhance the BRQ, which leads to fans' citizenship behaviors [34]. Similarly, Hudson et al. [35] adopt the BRQ perspective to examine the effects of marketing activities within social media on music festival fans' WOM intention toward festival brands. To summarize, the social media is quite suitable for managing customer relationships where the BRQ governing the relationship between the brand and its fans within social media-based brand community is becoming a prerequisite to CRM [23].

\subsection{Customer Engagement}

The engagement concept has received considerable academic and practitioner interest currently. Existing literature has studied several engagement concepts, such as consumer engagement [16], brand engagement [9], customer engagement [19], and customer engagement behaviors [36]. Because the CRM is a key responsibility of marketing function, the customer engagement construct is used more widely than other constructs [37]. Further, some research views customer engagement as a multidimensional concept including cognitive, emotional, and behavioral dimensions [38], or comprising emotional, cognitive, and social dimensions [39]. Some researchers also limit their focus to customer engagement behaviors. For instance, Van Doorn et al. [36] state that customer engagement is "a customer's behavioral manifestation toward a brand or firm, beyond purchases, resulting from motivational drivers" (p. 253). Specially, Harmeling et al. [40] suggest that defining customer engagement behaviorally rather than psychologically could be preferable because this helps to distinguish customer engagement from some psychological constructs (e.g., involvement, brand love, and commitment).

Regarding the essence of customer engagement, Vivek et al. [41] state that customer engagement comprises all the activities of customers with the firm. Pansari and Kumar [19] 
suggest that customer engagement has positive impacts on a firm and define it as "the mechanics of a customer's value addition to the firm, either through direct or/and indirect contribution" (p. 295). The direct contribution is primarily in the form of customer purchase, and the indirect contribution is primarily in the form of customer referrals, customer influence, and customer feedback [19]. Generally, research tends to take an inductive approach to turn to examples used previously to illustrate customer engagement, for example, purchasing, WOM, blogging, rating, liking, sharing, commenting, contributing, creating, etc. $[14,40,42]$.

Recently, brand community research has adopted customer engagement to reveal the effectiveness of firms' community marketing activities, in which the customer engagement was utilized as brand community engagement. The brand community engagement refers to customers' altruistic behaviors, namely, participating in value co-creation for themselves, other members, or the community creator $[9,13,17,43]$. Following these studies, this research views customer engagement as fan engagement consistent with the social media-based brand community context. Further, this study takes an inductive approach to define fan engagement behaviorally via determining the willingness to buy, membership continuance intention, and electronic word of mouth (eWOM) intention as the fan engagement. Defining fan engagement using these three concrete activities not only reflects the fans' direct and indirect contributions to the brands as well as community members but also establishes the linkage with firm's short- and long-term marketing performance.

\section{Hypotheses Development}

Hennig-Thurau and Klee [44] define relationship quality as "the degree of appropriateness of a relationship to fulfill the needs of the customer" (p. 751), suggesting that firms knowing and satisfying their customers' needs determine the strength of customer relationships. In this vein, this study first uncovers the needs or motivations behind fan engaging with social media-based brand communities. Previous research has revealed that consumers have varying motivations to join a brand community when on social media. For example, Zhou et al. [45] confirm that the utilitarian, hedonic, and social benefits could determine consumers' continuance intention toward the social virtual world. Buzeta et al. [12] and Gao and Feng [46] suggest that individuals using the social media seek information, entertainment, social interaction, self-expression, and impression management. The brand community embedded in social media is endowed with the social media characteristics and therefore is more likely to help members to achieve these goals. Further, Bento et al. [9] reveal that the information-, promotion-, entertainment-, and conversation-seeking motivations are key determinants of consumers interacting with brands through Facebook. Similarly, Bapna et al. [14] propose that consumers seeking opinions, product information, association with experts, contest and monetary incentives are willing to engage in Facebook brand communities. Based on these studies, this study proposes that the brand fan who joins social media-based brand communities intends to earn utilitarian, hedonic, social, and monetary benefits from the engaging host brand.

To provide these four types of benefits to fans, this study suggests that the brandas an excellent and active partner within social media-based brand community-usually strives to: (1) produce and provide high quality brand content for fans who can be informed and entertained; (2) encourage fans to participate in value co-creation activities, in which the fans' social connections could be enhanced; and (3) provide monetary incentives to fans who are active within the community. Further, according to the needs theory, when needs exist, an individual is motivated to take action to remove or fulfill these needs [47]. Consequently, the brand that helps fans fulfill their needs via providing a variety of specific benefits could lead to pleasant fan experience, which is likely to enhance relationship quality $[21,48,49]$. This study addresses the relationships between fans' needs fulfillments and BRQ as follows. 


\subsection{Brand Content Consumption and $B R Q$}

According to $\mathrm{Wu}$ et al. [50], most brand fans engage in brand communities to procure various information and/or entertaining content. Essentially, brand content entailing a large assortment of components is more than a form of advertisement. It resembles "storytelling," which promotes communication between fans and brands, during which the useful consumption-related information and entertaining content could be transferred to fans [51]. Admittedly, fans sometimes access some negative consumer-generated brand content (story) regarding product-harm crises during brand content consumption, which is likely to harm the brand [52]. This is one of the reasons the effectiveness of social media marketing has been suspected. However, as this study focuses on the interactions between the brand and fan in line with Fournier [2], the drivers of the BRQ are proposed to be related to the activities of brands rather than consumers. Previous research proposes that the brand continuously presenting fans with useful brand information as well as entertainment via propelling well-designed brand content could help to promote brand-fan relationships (e.g., $[13,53])$.

Meanwhile, following the advertising value perspective [54], brand content can provide fans with both utilitarian and hedonic values [42]. Consequently, brand content that includes informative and entertaining components could directly lead to brand fans perceiving its value and therefore being satisfied with the host brand. Park and Kim [8] demonstrate that the experiential and functional benefits obtained from the brand content are strong drivers of BRQ. Considered in conjunction-as the brand keeps its promises and enables the fans to fulfill both information and entertainment needs during the content consumption - this study posits two hypotheses as follows:

Hypotheses 1 (H1). Information needs fulfillment has a positive effect on $B R Q$.

Hypotheses 2 (H2). Entertainment needs fulfillment has a positive effect on BRQ.

\subsection{Social Interaction Needs Fulfillment and BRQ}

Self-determination theory (SDT; [55]) identifies three essential needs of humans that lead to psychological satisfaction and well-being: autonomy, competence, and relatedness. The need for relatedness refers to individuals longing for feeling connected to and understood by others. Virtual communities provide individuals an environment wherein they can socialize with others to seek relatedness needs fulfillment [45]. Based on Gao and Feng [46] and Pai and Arnott [56], this study proposes that brand fans' social interaction needs imply brand fans' tendency to secure social support, maintain existing relationships, and/or develop new friends to improve their relatedness within a brand community.

Psychological research has confirmed that frequent and pleasant social interactions between individuals can lead to closeness and interdependence (e.g., [57]). Patrick et al. [58] utilize the SDT theory to reveal that the relatedness needs fulfillment has the strongest effect of any of the needs fulfillments on relationship quality including satisfaction and commitment. Within the social media brand community context, brands not only directly interact with fans but also facilitate fan interactions with each other to effectively fulfill the needs of social interaction [39]. For instance, brand fans can comment on and/or share brand content and directly communicate with other fans in the brand communities, which contributes to promoting interpersonal relationships [9]. Furthermore, brand fans are often encouraged to participate in collaborative activities such as user-generated brand content and brainstorming campaigns where fans with common interests can build close interpersonal relationships $[15,59]$. Accordingly, this study supposes that brand fans who achieve their social interaction aspirations will be satisfied with the brand that keeps the promise of relatedness. Therefore, this study posits the following hypothesis:

Hypotheses 3 (H3). Social interaction needs fulfillment has a positive effect on $B R Q$. 


\subsection{Monetary Needs Fulfillment and BRQ}

Monetary incentives referring to firms providing financial rewards to customers to increase their financial benefits and economic utilities are usually applied in CRM (e.g., [60,61]). The use of monetary incentives is a well-known marketing approach that is effective in enhancing customer relationship by emphasizing customers' extrinsic motivation [42,62]. Therefore, marketers usually offer monetary incentives to brand fans to increase their enthusiasm and nurture the brand community [14,63]. At the same time, firms providing monetary incentive to customers could make customers perceive their extra effort and resource investment, which results in consumers' psychological bonding [64]. Accordingly, a brand can enable its fans to fulfill their monetary needs as it keeps its promise by offering incentives to them; and then, the monetary needs fulfillment may result in brand fans being more satisfied with the host brand. Thus, this study proposes the following hypothesis:

\section{Hypotheses 4 (H4). Monetary needs fulfillment has a positive effect on BRQ.}

\subsection{BRQ and Fan Engagement}

Some researchers suggest that customer engagement (behavior) consists of purchasing behavior, referral (recommendation) behavior, helping behavior, and co-creation corresponding to the focal object (e.g., $[19,36,65,66])$. Similarly, observing the frequent fan behaviors in a social media-based brand community, this study determines the willingness to buy, membership continuance intention, and eWOM intentions as the fans' engagement behavioral intentions. Willingness to buy refers to a brand fan's intention to purchase products from the brand [19]. Promoting fans' willingness to purchase products could directly enhance firms' financial performances [67]. Membership continuance intention refers to the fans' intention to maintain their memberships and ties to the engaging brand community in the future, which plays a crucial role in long-term community development $[25,68]$. The eWOM intention refers to brand fans' intention to recommend the host brand to their friends via the internet $[36,69]$. The essence of WOM is sharing an individual's brand experiences with other consumers [66]. Therefore, positive eWOM is conjectured to promote potential customers' brand attitude and further increase purchase intention [70].

Existing literature has explored behavioral brand loyalty such as product purchase, WOM, and membership continuance as consequences of firms' investments in customer relationship (e.g., [66,71]). Similarly, customer engagement occurs depending on interactive and pleasant customer experiences with a brand or firm [16,37,38]. Fournier [2] emphasizes that the relationships formed between a brand and its customers are reciprocal. Accordingly, a brand that keeps its promises to a sufficient degree with regard to supporting fans in fulfilling their needs could not only enhance the BRQ but also further result in fans community engagement behaviors toward the brand. Pansari and Kumar [19] suggest that when a customer perceives brand relationship is satisfied, this relationship then progresses to the stage of customer engagement. Moreover, cognitive consistency theory suggests that individuals tend to keep their behaviors consistent with their cognitive beliefs and feelings to achieve psychological harmony [72]. Following this theory, Sheth and Parvatiyar [1] propose that firms' investments in relationship marketing could promote consumers' reciprocal behaviors toward the brands. In the same vein, as BRQ reflects brand fans' positive psychological responses to the brand which suitably keeps its promises, brand fans are likely to perform engagement behaviors to maintain their cognitive consistency. Accordingly, the following three hypotheses are proposed:

Hypotheses 5 (H5). BRQ has a positive effect on willingness to buy.

Hypotheses 6 (H6). BRQ has a positive effect on membership continuance intention. Hypotheses 7 (H7). BRQ has a positive effect on eWOM intention.

This study addresses the effects of the four kinds of brand fan needs fulfillment on BRQ which elicits fan engagement behavioral intentions toward the brand to reveal how brand fans evaluate and respond to the brand that keeps promises and interacts with them 
adequately in the context of social media-based brand communities. Figure 1 presents the research model.

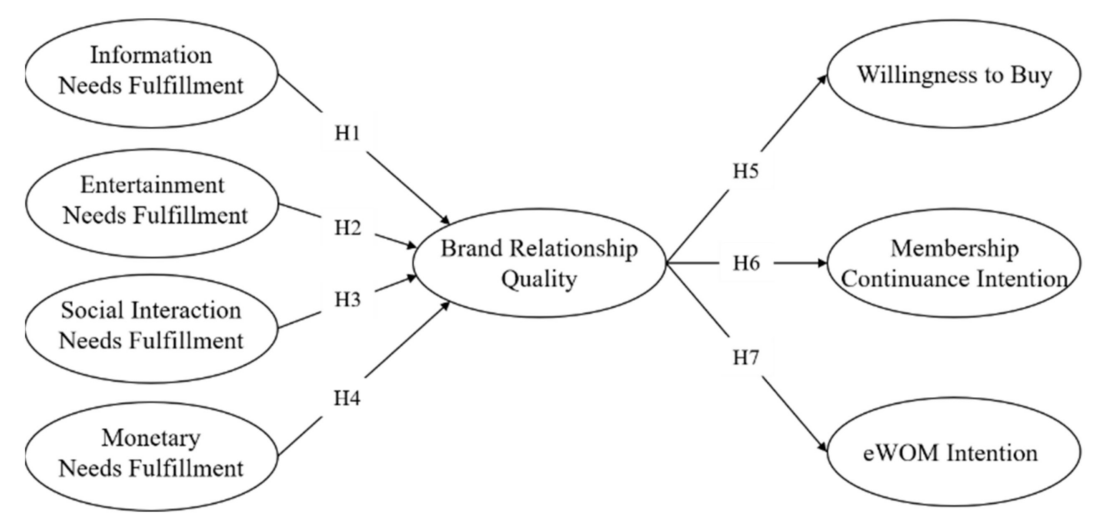

Figure 1. Research Model.

\section{Research Method}

This study addresses the BRQ working mechanism in the social media-based brand community context; thus, the unit of analysis is at individual level (i.e., brand fans who have joined brand communities when using the social media). This study conducts an empirical study by using an online survey method for data collection and hypotheses test.

\subsection{Measurements}

This study has eight constructs, of which the measurement items were drawn from prior studies and slightly modified to ensure the appropriateness for this study. All research variables were measured using a seven-point Likert scale (i.e., $1=$ strongly disagree, $7=$ strongly agree). Table 1 indicates detailed measurements and related sources.

Table 1. Measurement items for constructs.

\begin{tabular}{|c|c|c|}
\hline Constructs & Items & Sources \\
\hline \multirow{5}{*}{$\begin{array}{l}\text { Information Needs } \\
\text { Fulfillment }\end{array}$} & $\begin{array}{l}\text { 1. I get relevant information on products from brand content } \\
\text { consumption. (INF1) }\end{array}$ & \multirow{5}{*}{$\begin{array}{l}\text { Gao and Feng [46]; } \\
\text { Ducoffe [54] }\end{array}$} \\
\hline & $\begin{array}{l}\text { 2. I get timely information on products from brand content } \\
\text { consumption. (INF2) }\end{array}$ & \\
\hline & $\begin{array}{l}\text { 3. Brand content tells me about products when I need the } \\
\text { information. (INF3) }\end{array}$ & \\
\hline & $\begin{array}{l}\text { 4. I collect information for future use from brand content } \\
\text { consumption. (INF4) }\end{array}$ & \\
\hline & 5. I learn a lot from brand content consumption. (INF5) & \\
\hline \multirow{4}{*}{$\begin{array}{l}\text { Entertainment Needs } \\
\quad \text { Fulfillment }\end{array}$} & 1. Brand content is entertaining. (ENF1) & \multirow{4}{*}{$\begin{array}{l}\text { Gao and Feng [46]; } \\
\text { Ducoffe [54] }\end{array}$} \\
\hline & 2. Brand content is enjoyable. (ENF2) & \\
\hline & 3. Brand content is pleasing. (ENF3) & \\
\hline & 4. Brand content is exciting. (ENF4) & \\
\hline \multirow{5}{*}{$\begin{array}{l}\text { Social Interaction Needs } \\
\text { Fulfillment }\end{array}$} & 1. I get information about other members. (SINF1) & \multirow{5}{*}{ Gao and Feng [46] } \\
\hline & 2. I communicate and interact with other members. (SINF2) & \\
\hline & 3. I show concern and support to other members. (SINF3) & \\
\hline & 4. I get opinions and advice from other members. (SINF4) & \\
\hline & 5. I express my ideas and advice to other members. (SINF5) & \\
\hline
\end{tabular}


Table 1. Cont.

\begin{tabular}{|c|c|c|}
\hline Constructs & Items & Sources \\
\hline \multirow{3}{*}{ Monetary Needs Fulfillment } & 1. This brand offers incentives, such as bonus points. (MNF1) & \multirow{3}{*}{ Yoo et al. [60] } \\
\hline & 2. I get rewarded for my use of this brand community. (MNF2) & \\
\hline & $\begin{array}{l}\text { 3. I get discount coupons from the brand when I am in the brand } \\
\text { community. (MNF3) }\end{array}$ & \\
\hline \multirow{6}{*}{ Brand Relationship Quality } & 1. I am very loyal to this brand. (BRQ1) & \multirow{6}{*}{$\begin{array}{l}\text { Park and Kim [8]; } \\
\text { Huber et al. [22] }\end{array}$} \\
\hline & 2. I would stick to this brand even if it let me down once. (BRQ2) & \\
\hline & $\begin{array}{l}\text { 3. I feel like something is missing when I don't use the brand for a } \\
\text { while. (BRQ3) }\end{array}$ & \\
\hline & 4. This brand plays an important role in my life. (BRQ4) & \\
\hline & 5. This brand treats me well. (BRQ5) & \\
\hline & 6. I trust this brand. (BRQ6) & \\
\hline \multirow{3}{*}{ Willingness to Buy } & 1. The likelihood of purchasing this brand is high. (WTB1) & \multirow{3}{*}{ Yeh and Li [67] } \\
\hline & $\begin{array}{l}\text { 2. The probability that I would consider buying this brand is high. } \\
\text { (WTB2) }\end{array}$ & \\
\hline & 3. My willingness to buy this brand is high. (WTB3) & \\
\hline \multirow{3}{*}{$\begin{array}{l}\text { Membership Continuance } \\
\text { Intention }\end{array}$} & $\begin{array}{l}\text { 1. It would be very difficult for me to leave this brand community. } \\
\text { (MCI1) }\end{array}$ & \multirow{3}{*}{ Wang et al. [68] } \\
\hline & 2. I intend to stay on as a brand community member. (MCI2) & \\
\hline & $\begin{array}{l}\text { 3. I am willing to invest more effort to be a member of this brand } \\
\qquad \text { community. (MCI3) }\end{array}$ & \\
\hline \multirow{3}{*}{ eWOM Intention } & $\begin{array}{l}\text { 1. I will say positive things about this brand to other people via the } \\
\text { Internet. (eWOMI1) }\end{array}$ & \multirow{3}{*}{$\begin{array}{l}\text { Fernandes and Pinto [21]; } \\
\text { Eisingerich et al. [69] }\end{array}$} \\
\hline & $\begin{array}{l}\text { 2. I will encourage friends and relatives to do business with this } \\
\text { brand via the Internet. (eWOMI2) }\end{array}$ & \\
\hline & $\begin{array}{l}\text { 3. I will recommend this brand to someone who seeks my advice via } \\
\text { the Internet. (eWOMI3) }\end{array}$ & \\
\hline
\end{tabular}

\subsection{Data Collection}

Facebook is one of the most popular social media marketing platforms [9,14]. According to Statista [73], the Facebook is now the biggest social network worldwide, having nearly 2.8 billion global monthly active users, as of the fourth quarter of 2020. In South Korea, the Facebook is also widely used as a social media marketing platform [74]. Therefore, this study selected brand fans from communities facilitated by Facebook for data collection.

This study utilized the Sojump data gathering platform (http:/ / www.sojump.com) to implement online surveys. A virtual snowball sampling technique was employed to share and forward the survey links on KaKao Talk, a dominant Korean social networking service, which can help collect data from a general population in South Korea. Respondents in South Korea were asked to answer whether they had participated in any of the brand communities while using Facebook. If the respondents answered " $\mathrm{No}^{\prime}$, he or she had to terminate the completion of the questionnaire. The participant who answered "Yes" were then requested to record one of the brand community names on the opening page of the questionnaire. Consequently, 234 participants were collected and then analyzed. Meanwhile, the brand community names were verified, and more than 100 brand communities were included in this study. The most mentioned, top-three brands among them were Samsung (15), Nike (12), and Gmarket (7). Others include LG, Lotteria, CJ mall, Starbucks, Adidas, Uniqlo, and so on. Table 2 presents the demographic summary information of respondents. Specially, in terms of age and education of the respondents, 65.8 percent of the respondents were aged 
20-29, and 71.4 percent of respondents were undergraduate, which is nearly consistent with some statistics showing 87 percent of South Korean people aged between 20 and 29 years old use the social media [75].

Table 2. Descriptive statistics of respondents' characteristics $(n=234)$.

\begin{tabular}{cccc}
\hline Category & Item & Frequency & Percentage \\
\hline \multirow{2}{*}{ Gender } & Male & 135 & $57.7 \%$ \\
\cline { 2 - 4 } & Female & 99 & $42.3 \%$ \\
\cline { 2 - 4 } & $<20$ & 19 & $8.1 \%$ \\
\cline { 2 - 4 } Age & $20-29$ & 154 & $65.8 \%$ \\
\cline { 2 - 4 } & $30-39$ & 39 & $16.7 \%$ \\
\cline { 2 - 4 } & $>39$ & 22 & $9.4 \%$ \\
\cline { 2 - 4 } Education & $<$ Undergraduate & 167 & $1.7 \%$ \\
\cline { 2 - 4 } & Undergraduate & 63 & $71.4 \%$ \\
\cline { 2 - 4 } & Postgraduate & 136 & $26.9 \%$ \\
\hline \multirow{2}{*}{ Occupation } & Student & 98 & $58.1 \%$ \\
\cline { 2 - 4 } & Total & Nonstudent & $100 \%$ \\
\hline
\end{tabular}

\section{Data Analysis and Results}

\subsection{Reliability and Validity}

This study employed Smart PLS 3.0 to perform a confirmatory factor analysis (CFA) to investigate reliability and validity. Table 3 indicates the CFA results. The values of Cronbach's $\alpha$ and composite reliability (CR) of the constructs were greater than the value of 0.7, indicating an acceptable internal consistency and reliability [76]. To verify the convergent validity of constructs, this study followed Fornell and Larcker [76]. The standardized factor loadings of indicators for all constructs are significantly higher than 0.7 , the $C R$ values are greater than 0.7 , and the average variance extracted (AVE) values for all constructs exceed the minimum, 0.5 , which indicates an acceptable convergent validity level.

Further, following Fornell and Larcker [76], this study compared the square root of the AVE value for each construct with the inter-construct correlation estimates to examine the discriminant validity. Table 4 shows the construct correlation estimates and square roots of the AVE values (the diagonal elements in bold) for constructs. Each square root of AVE is greater than its corresponding row and column elements, suggesting adequate discriminant validity. In addition, following Hair et al. [77], this study assessed HeterotraitMonotrait Ratio of correlations (HTMT) to establish more rigorous discriminant validity. All of the HTMT values are significantly different from 1, and the largest HTMT value is 0.737 that was lower than the cut-off value of 0.90 , showing the evidence of adequate discriminant validity.

\subsection{Multicollinearity and Common Method Bias Tests}

Because some constructs exhibited more or less high correlations, this study verified the variable inflation factor (VIF) values for examining the potential multicollinearity, based on Tabachnick and Fidell [78]. The VIF values of predicting variables did not exceed the threshold value of 10.0 (between 1.000 and 1.729), indicating no multicollinearity problems. Furthermore, based on Podsakoff and Organ [79], this study conducted a Harman's onefactor test for establishing the common method bias (CMB). The analyses indicated that there were seven latent factors exceeding 1.0 of the eigenvalues, with the first factor accounting for less than $50 \%$ of the total variance (i.e., $41.4 \%$ ), suggesting that $\mathrm{CMB}$ is not a significant threat in this study. 
Table 3. Results of reliability and convergent validity tests.

\begin{tabular}{|c|c|c|c|c|c|}
\hline Construct & Indicator & $\begin{array}{c}\text { Standardized } \\
\text { Factor Loading }\end{array}$ & AVE & CR & Cronbach's $\alpha$ \\
\hline \multirow{5}{*}{$\begin{array}{l}\text { Information Needs } \\
\text { Fulfillment }\end{array}$} & INF1 & 0.838 & \multirow{5}{*}{0.695} & \multirow{5}{*}{0.919} & \multirow{5}{*}{0.890} \\
\hline & INF2 & 0.834 & & & \\
\hline & INF3 & 0.844 & & & \\
\hline & INF4 & 0.856 & & & \\
\hline & INF5 & 0.796 & & & \\
\hline \multirow{4}{*}{$\begin{array}{l}\text { Entertainment Needs } \\
\text { Fulfillment }\end{array}$} & ENF1 & 0.798 & \multirow{4}{*}{0.770} & \multirow{4}{*}{0.930} & \multirow{4}{*}{0.900} \\
\hline & ENF2 & 0.916 & & & \\
\hline & ENF3 & 0.906 & & & \\
\hline & ENF4 & 0.884 & & & \\
\hline \multirow{5}{*}{$\begin{array}{l}\text { Social Interaction Needs } \\
\text { Fulfillment }\end{array}$} & SINF1 & 0.776 & \multirow{5}{*}{0.795} & \multirow{5}{*}{0.951} & \multirow{5}{*}{0.934} \\
\hline & SINF2 & 0.934 & & & \\
\hline & SINF3 & 0.922 & & & \\
\hline & SINF4 & 0.894 & & & \\
\hline & SINF5 & 0.922 & & & \\
\hline \multirow{3}{*}{$\begin{array}{l}\text { Monetary Needs } \\
\text { Fulfillment }\end{array}$} & MNF1 & 0.936 & \multirow{3}{*}{0.862} & \multirow{3}{*}{0.949} & \multirow{3}{*}{0.920} \\
\hline & MNF2 & 0.954 & & & \\
\hline & MNF3 & 0.895 & & & \\
\hline \multirow{6}{*}{$\begin{array}{l}\text { Brand Relationship } \\
\text { Quality }\end{array}$} & BRQ1 & 0.836 & \multirow{6}{*}{0.680} & \multirow{6}{*}{0.927} & \multirow{6}{*}{0.906} \\
\hline & BRQ2 & 0.833 & & & \\
\hline & BRQ3 & 0.734 & & & \\
\hline & BRQ4 & 0.844 & & & \\
\hline & BRQ5 & 0.840 & & & \\
\hline & BRQ6 & 0.856 & & & \\
\hline \multirow{3}{*}{ Willingness to Buy } & WTB1 & 0.954 & \multirow{3}{*}{0.900} & \multirow{3}{*}{0.964} & \multirow{3}{*}{0.944} \\
\hline & WTB2 & 0.939 & & & \\
\hline & WTB3 & 0.952 & & & \\
\hline \multirow{2}{*}{$\begin{array}{c}\text { Membership } \\
\text { Continuance Intention * }\end{array}$} & MCI2 & 0.974 & \multirow{2}{*}{0.943} & \multirow{2}{*}{0.971} & \multirow{2}{*}{0.940} \\
\hline & MCI3 & 0.968 & & & \\
\hline \multirow{3}{*}{ eWOM Intention } & eWOMI1 & 0.945 & \multirow{3}{*}{0.899} & & \\
\hline & eWOMI2 & 0.951 & & 0.964 & 0.944 \\
\hline & eWOMI3 & 0.948 & & & \\
\hline
\end{tabular}

* The first item of membership continuance intention (MCI1) was deleted during the CFA process. 
Table 4. Construct correlations and discriminant validity.

\begin{tabular}{ccccccccccc}
\hline & Mean & S.D. & $\mathbf{1}$ & $\mathbf{2}$ & $\mathbf{3}$ & $\mathbf{4}$ & $\mathbf{5}$ & $\mathbf{6}$ & $\mathbf{7}$ & $\mathbf{8}$ \\
\hline 1. BRQ & 3.726 & 1.405 & $\mathbf{0 . 8 2 5}$ & & & & & & & \\
\hline 2. MCI & 4.295 & 1.577 & 0.668 & $\mathbf{0 . 9 7 1}$ & & & & & & \\
\hline 3. INF & 4.686 & 1.248 & 0.532 & 0.562 & $\mathbf{0 . 8 3 4}$ & & & & & \\
\hline 4. eWOMI & 4.235 & 1.562 & 0.689 & 0.663 & 0.465 & $\mathbf{0 . 9 4 8}$ & & & & \\
\hline 5. ENF & 4.310 & 1.345 & 0.495 & 0.406 & 0.616 & 0.412 & $\mathbf{0 . 8 7 7}$ & & & \\
\hline 6. SINF & 3.389 & 1.688 & 0.438 & 0.345 & 0.338 & 0.351 & 0.403 & $\mathbf{0 . 8 9 2}$ & & \\
\hline 7. WTB & 4.637 & 1.484 & 0.635 & 0.561 & 0.483 & 0.587 & 0.256 & 0.187 & $\mathbf{0 . 9 4 9}$ & \\
\hline 8. MNF & 3.268 & 1.694 & 0.389 & 0.219 & 0.190 & 0.238 & 0.187 & 0.425 & 0.222 & $\mathbf{0 . 9 2 9}$ \\
\hline
\end{tabular}

BRQ: Brand Relationship Quality, MCI: Membership Continuance Intention, INF: Information Needs Fulfillment, eWOMI: eWOM Intention, ENF: Entertainment Needs Fulfillment, SINF: Social Interaction Needs Fulfillment, WTB: Willingness to Buy, MNF: Monetary Needs Fulfillment.

\subsection{Hypotheses Tests}

To test the presented hypotheses, this study utilized Smart PLS 3.0 to perform a path analysis. The hypotheses test results are presented in Figure 2. Information, entertainment, social interaction, and monetary needs fulfillments significantly and positively affected $\operatorname{BRQ}(\beta=0.316, p<0.001 ; \beta=0.196, p<0.01 ; \beta=0.156, p<0.05 ; \beta=0.226, p<0.01)$. Thus, H1, H2, H3, and H4 are supported. Furthermore, BRQ was confirmed to have a positive impact on willingness to buy, membership continuance intention as well as eWOM intention $(\beta=0.635, p<0.001 ; \beta=0.668, p<0.001 ; \beta=0.689, p<0.001)$. Therefore, the three hypotheses of $\mathrm{H} 5, \mathrm{H} 6$, and $\mathrm{H} 7$ are all supported.

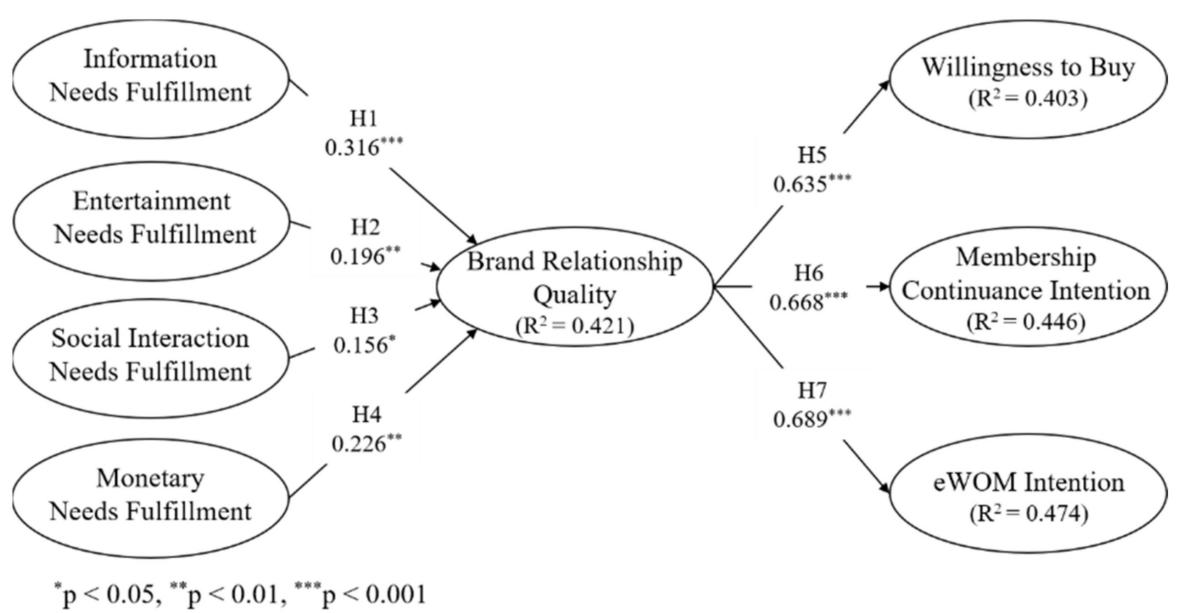

Figure 2. Hypotheses Test Results.

This study further attempted to understand the role of BRQ in mediating the relationships between fan needs fulfillment and fan engagement behaviors. Following Hair et al. [77], this study found that both the indirect and direct effects were significant and in the same direction, suggesting BRQ played a partial mediator role.

\section{Discussion and Implications}

\subsection{Key Findings}

Brands worldwide are investing substantial amounts in brand communities on social media platforms to develop customer-brand relationships [13,18], which calls for more empirical studies regarding the marketing activities and performance metrics to encourage a deeper understanding of the effectiveness of social media-based brand communities. The findings of this study suggest that all of the hypotheses are supported and the BRQ 
partially mediates the effects of fan needs fulfillment on fan engagement behaviors. These fulfillments of the information, entertainment, social interaction, and monetary needs could increase the BRQ significantly, which not only corresponds to the previous studies (e.g., [8,23]) but also provides the apparent evidence that the information, entertainment, social interaction, and promotion seeking motivations of Facebook brand fans suggested by Bento et al. [9] and Bapna et al. [14] do exist. Meanwhile, the BRQ could encourage fans' willingness to buy, membership continuance intention, and eWOM intention, which is consistent with existing literature such as Hudson et al. [35] and Prentice et al. [66]. Based on the study findings, theoretical contributions and managerial implications are discussed in the next subsections.

\subsection{Theoretical Contributions}

As using social media has become a substantial part of consumer online activities, firms are keen to integrate their marketing efforts with consumers' activities on social media $[7,13,61]$. This study makes several contributions for better understanding of the steps taken to make fans engage with the host brands within social media-based brand communities. First, the BRQ is an alternative to attitudinal brand loyalty and offers a comparative advantage in highlighting consumer-brand relationship formation [2]. This research proves that brands, as active objects, help consumers fulfill needs in many ways through interacting with their fans and building strong relationships with fans, which adheres to the consensus that the evaluation of BRQ should be based on the experience provided to consumers [21]. Four forms of needs fulfillment from utilitarian, hedonic, social, and economic aspects based on fans' motivations to join brand community were derived. Although these needs fulfillment can be found in the traditional brand communities, they can be more dynamic and representative in the context of social media-based brand community environment, as the social media may greatly enhance the interactions between fans and brands.

Second, fan engagement is not only an outcome measure of a firm's CRM activities [19,41], but it is also associated with subsequent growth of the community [14]. This study confirmed that enhancing BRQ via satisfying fans' needs could lead to fan engagement behaviors. Further, this study verified that the BRQ played the partial mediator role between fan needs fulfillment and engagement behaviors, which addresses the working mechanism of BRQ in social media-based brand communities.

Third, this study contributes to the existing literature pertaining to social media in business. Brand community is an important component of social media that can be used to perform relationship marketing [10,71]. This study emphasizes that social media-based brand communities can play a valuable role as a bridge between the brand and its fans. This study extended upon Dolan et al.'s [65] study that called for the development of a theoretical model describing the roles of brand fans within social media by linking brand fans' needs fulfillment, BRQ, and fan engagement behaviors.

\subsection{Managerial Implications}

This research could first help marketers to better understand how to trigger and build consumer-brand relationships in social media marketing. If the brand fans within social media-enabled brand communities could fulfill their informational, entertainment, social, and economic needs, they will demonstrate an elevated level of satisfaction with the engaging brands. Therefore, marketers should react quickly to what brand fans want in social media-based brand communities [14]. This finding contributes to better understanding the reason marketers continuously update their fan pages and posts with valuable and/or interesting content, launch value co-creation campaigns, and offer incentives to brand fans. For example, Dell endeavors to build its brand community via social media by declaring this: "Welcome to the community! Join the conversation, collaborate with others, and get valuable information you won't find anywhere else". 
Second, although many marketers obtain some success through Facebook brand fan membership, most of them continue to struggle to effectively engage the brand fans [80]. This study offers apparent evidence that marketers who intend to combine brand communities with social media could maintain and enhance the fan relationships and thereby foster marketing performance. It is important to note that there is no shortcut to improve relationship marketing performances. Acquiring brand fans via social media is just the beginning; marketers should pay more attention to understanding brand fans' psychological needs more accurately and gradually build long-term dyadic relationships with the fans [15]. If not, the brand fans will lose touch with the host brands and gradually become zombie fans, implying the brand is likely to lose key operant resources in value co-creation.

Third, this study suggests that special efforts should be made to indulge brand fans and create a feeling of being valuable partners whose engagement behaviors are significant to brands, as fan engagement is assumed to have positive outcomes for brands and their virtual brand communities [53]. Willingness to buy, membership continuance intention, and eWOM intention discussed in this study have the potential to increase companies business performances. Thus, these study findings contribute to a broader understanding that increasing the investment in social media marketing is extremely necessary and essential for a firm.

Finally, regarding the COVID-19 pandemic, most of the B2C firms are struggling to overcome economic decline, failing to secure customer retention. They seek some effective marketing strategies, changing the way of business from offline to online. The enhancement of the fan BRQ is a cost-effective way of sales recovery for firms which step down from sales with face-to-face communications/interactions with their potential customers not available by the COVID-19 pandemic. The concept of the BRQ can give a new opportunity of the sales backup to firms via original online and mobile brand marketing in the COVID-19 pandemic era. Because customer acquisition and retention may become more difficult in firms by the COVID-19 pandemic, the use of the BRQ needs to be reconsidered. In particular, during an economic downturn caused by the COVID-19 pandemic, small- and medium-sized enterprises (SMEs) investing in social media marketing platforms could better heighten intimate connections with their customers, which contributes to their firm survival and performance [81].

\section{Conclusions and Research Limitations}

This research emphasizes the importance of the BRQ in a social media-based brand community which can increase firm's marketing performance, seeking to reveal a new and effective way to enhance fan engagement via adopting the BRQ perspective. An empirical analysis with 234 Facebook users found that the brand fan's core need fulfillments could affect his or her BRQ, which leads to fan engagement such as willingness to buy, membership continuance intention, and eWOM intention. All of the hypotheses in the research model were supported by the statistical analyses, and their interpretations were provided for the readers. Academic and practical implications of the research findings were also discussed. However, this study has several limitations that show avenues for future research.

First, this study tested research hypotheses regarding relationships between fan needs fulfillment, BRQ, and fan engagement behaviors, where the relationship norms that include exchange relationship norms and communal relationship norms might play the moderating role $[82,83]$. Thus, it is interesting to consider relationship norms as a moderating variable in the BRQ research. Second, this study selected the Facebook brand community as research object. However, as the brand fan's community experiences could vary according to the different business operating activities as well as technological features of each social media, future research is recommended to conduct cross-cultural examination regarding the different social media marketing platforms (e.g., Twitter, Weibo, Instagram, etc.) to support the generalization of findings, like Buzeta et al. [12] and Hudson et al. [59]. Finally, this study applied snowball sampling for data collection. It should be noted that this 
technique is likely to cause nonrandom, sampling error, community bias, or lack of control. Therefore, future research that uses a random sampling approach and gathers larger samples is recommended.

Author Contributions: Conceptualization, L.L., Y.J., and J.K.; methodology, L.L. and J.K.; software, L.L.; validation, L.L., Y.J., and J.K.; formal analysis, L.L.; investigation, L.L. and J.K.; resources, L.L.; data curation, Y.J. and J.K.; writing—original draft preparation, L.L.; writing—review and editing, J.K.; visualization, L.L.; supervision, J.K.; project administration, J.K. and Y.J.; funding acquisition, Y.J. All authors have read and agreed to the published version of the manuscript.

Funding: This research was funded by the National Social Science Fund of China (Grant No. 18BGL114).

Institutional Review Board Statement: Not applicable.

Informed Consent Statement: Not applicable.

Data Availability Statement: The data presented in this study are available on request from the corresponding author.

Conflicts of Interest: The authors declare no conflict of interest.

\section{References}

1. Sheth, J.N.; Parvatlyar, A. Relationship marketing in consumer markets: Antecedents and consequences. J. Acad. Mark. Sci. 1995, 23, 255-271. [CrossRef]

2. Fournier, S. Consumers and their brands: Developing relationship theory in consumer research. J. Consum. Res. 1998, 24, 343-353. [CrossRef]

3. Nyffenegger, B.; Krohmer, H.; Hoyer, W.D.; Malaer, L. Service brand relationship quality: Hot or cold? J. Serv. Res. 2015, 18, 90-106. [CrossRef]

4. Kotler, P.; Kartajaya, H.; Setiawan, I. Marketing 4.0: Moving from Traditional to Digital; John Wiley \& Sons: Hoboken, NJ, USA, 2016.

5. Jiménez-Zarco, A.I.; Rospigliosi, A.; Martínez-Ruiz, M.P.; Izquierdo-Yusta, A. Marketing 4.0: Enhancing consumer-brand engagement through big data analysis. In Socio-Economic Perspectives on Consumer Engagement and Buying Behavior; IGI Global: Hershey, PA, USA, 2019; pp. 94-117.

6. Dash, G.; Kiefer, K.; Paul, J. Marketing-to-millennials: Marketing 4.0, customer satisfaction and purchase intention. J. Bus. Res. 2021, 122, 608-620. [CrossRef]

7. Labrecque, L.I. Fostering consumer-brand relationships in social media environments: The role of parasocial interaction. J. Interact. Mark. 2014, 28, 134-148. [CrossRef]

8. Park, H.; Kim, Y.-K. The role of social network websites in the consumer-brand relationship. J. Retail. Consum. Serv. 2014, 21, 460-467. [CrossRef]

9. Bento, M.; Martinez, L.M. Brand engagement and search for brands on social media: Comparing generations $\mathrm{X}$ and $\mathrm{Y}$ in Portugal. J. Retail. Consum. Serv. 2018, 43, 234-241. [CrossRef]

10. Gómez, M.; Lopez, C.; Molina, A. An integrated model of social media brand engagement. Comput. Hum. Behav. 2019, 96, 196-206. [CrossRef]

11. Han, S.; Min, J.; Lee, H. Building relationships within corporate SNS accounts through social presence formation. Int. J. Inf. Manag. 2016, 36, 945-962. [CrossRef]

12. Buzeta, C.; De Pelsmacker, P.; Dens, N. Motivations to use different social media types and their impact on consumers' online brand-related activities (COBRAs). J. Interact. Mark. 2020, 52, 79-98. [CrossRef]

13. Carlson, J.; Rahman, S.M.; Rahman, M.M.; Wyllie, J.; Voola, R. Engaging gen Y customers in online brand communities: A cross-national assessment. Int. J. Inf. Manag. 2021, 56, 102252. [CrossRef]

14. Bapna, S.; Benner, M.J.; Qiu, L. Nurturing online communities: An empirical investigation. MIS Q. 2019, 43, 425-452. [CrossRef]

15. Sanz-Blas, S.; Bigné, E.; Buzova, D.; Bigné-Alcañiz, E. Facebook brand community bonding: The direct and moderating effect of value creation behaviour. Electron. Commer. Res. Appl. 2019, 35, 100850. [CrossRef]

16. Brodie, R.J.; Ilic, A.; Juric, B.; Hollebeek, L. Consumer engagement in a virtual brand community: An exploratory analysis. J. Bus. Res. 2013, 66, 105-114. [CrossRef]

17. Kumar, J.; Kumar, V. Drivers of brand community engagement. J. Retail. Consum. Serv. 2020, 54, 101949. [CrossRef]

18. Wang, K.-Y.; Chih, W.-H.; Hsu, L.-C. Building brand community relationships on Facebook fan pages: The role of perceived interactivity. Int. J. Electron. Commer. 2020, 24, 211-231. [CrossRef]

19. Pansari, A.; Kumar, V. Customer engagement: The construct, antecedents, and consequences. J. Acad. Mark. Sci. 2017, 45, $294-311$. [CrossRef]

20. Smit, E.; Bronner, F.; Tolboom, M. Brand relationship quality and its value for personal contact. J. Bus. Res. 2007, 60, 627-633. [CrossRef] 
21. Fernandes, T.; Pinto, T. Relationship quality determinants and outcomes in retail banking services: The role of customer experience. J. Retail. Consum. Serv. 2019, 50, 30-41. [CrossRef]

22. Huber, F.; Vollhardt, K.; Matthes, I.; Vogel, J. Brand misconduct: Consequences on consumer-brand relationships. J. Bus. Res. 2010, 63, 1113-1120. [CrossRef]

23. Akrout, H.; Nagy, G. Trust and commitment within a virtual brand community: The mediating role of brand relationship quality. Inf. Manag. 2018, 55, 939-955. [CrossRef]

24. Sarkar, J.G.; Sarkar, A.; Balaji, M.S. The "Right-to-refuse-service" paradox: Other customers' perception of discretionary service denial. J. Bus. Res. 2020, 121, 686-695. [CrossRef]

25. Algesheimer, R.; Dholakia, U.M.; Herrmann, A. The social influence of brand community: Evidence from European car clubs. J. Mark. 2005, 69, 19-34. [CrossRef]

26. Athanasopoulou, P. Relationship quality: A critical literature review and research agenda. Eur. J. Mark. 2009, 43, 583-610. [CrossRef]

27. Batra, R.; Ahuvia, A.; Bagozzi, R.P. Brand Love. J. Mark. 2012, 76, 1-16. [CrossRef]

28. Ferreira, P.; Rodrigues, P.; Rodrigues, P. Brand love as mediator of the brand experience-satisfaction-loyalty relationship in a retail fashion brand. Manag. Mark. 2019, 14, 278-291. [CrossRef]

29. Gómez-Suárez, M. Examining customer-brand relationships: A critical approach to empirical models on brand attachment, love, and engagement. Adm. Sci. 2019, 9, 10. [CrossRef]

30. Liu, Y.; Kou, Y.; Guan, Z.; Hu, J.; Pu, B. Exploring hotel brand attachment: The mediating role of sentimental value. J. Retail. Consum. Serv. 2020, 55, 102143. [CrossRef]

31. Wang, T.; Thai, T.D.-H.; Ly, P.T.M.; Chi, T.P. Turning social endorsement into brand passion. J. Bus. Res. 2021, 126, 429-439. [CrossRef]

32. Mrad, M.; Cui, C.C. Comorbidity of compulsive buying and brand addiction: An examination of two types of addictive consumption. J. Bus. Res. 2020, 113, 399-408. [CrossRef]

33. Bengtsson, A. Towards a critique of brand relationships. Adv. Consum. Res. 2003, 30, 154-158.

34. Nyadzayo, M.; Matanda, M.J.; Ewing, M.T. Franchisee-based brand equity: The role of brand relationship quality and brand citizenship behavior. Ind. Mark. Manag. 2016, 52, 163-174. [CrossRef]

35. Hudson, S.; Roth, M.S.; Madden, T.J.; Hudson, R. The effects of social media on emotions, brand relationship quality, and word of mouth: An empirical study of music festival attendees. Tour. Manag. 2015, 47, 68-76. [CrossRef]

36. Van Doorn, J.; Lemon, K.N.; Mittal, V.; Nass, S.; Pick, D.; Pirner, P.; Verhoef, P.C. Customer engagement behavior: Theoretical foundations and research directions. J. Serv. Res. 2010, 13, 253-266. [CrossRef]

37. Hollebeek, L.D.; Srivastava, R.K.; Chen, T. S-D logic-informed customer engagement: Integrative framework, revised fundamental propositions, and application to CRM. J. Acad. Mark. Sci. 2019, 47, 161-185. [CrossRef]

38. Baldus, B.J.; Voorhees, C.; Calantone, R. Online brand community engagement: Scale development and validation. J. Bus. Res. 2015, 68, 978-998. [CrossRef]

39. Xi, N.; Hamari, J. Does gamification affect brand engagement and equity? A study in online brand communities. J. Bus. Res. 2020, 109, 449-460. [CrossRef]

40. Harmeling, C.M.; Moffett, J.W.; Arnold, M.J.; Carlson, B.D. Toward a theory of customer engagement marketing. J. Acad. Mark. Sci. 2017, 45, 312-335. [CrossRef]

41. Vivek, S.D.; Beatty, S.E.; Morgan, R.M. Customer engagement: Exploring customer relationships beyond purchase. J. Mark. Theory Pract. 2012, 20, 122-146. [CrossRef]

42. Chen, M.-H.; Tsai, K.-M. An empirical study of brand fan page engagement behaviors. Sustainability 2020, 12, 434. [CrossRef]

43. Carlson, J.; Rahman, M.; Voola, R.; de Vries, N. Customer engagement behaviours in social media: Capturing innovation opportunities. J. Serv. Mark. 2018, 32, 83-94. [CrossRef]

44. Hennig-Thurau, T.; Klee, A. The impact of customer satisfaction and relationship quality on customer retention: A critical reassessment and model development. Psychol. Mark. 1997, 14, 737-764. [CrossRef]

45. Zhou, Z.; Jin, X.L.; Fang, Y. Moderating role of gender in the relationships between perceived benefits and satisfaction in social virtual world continuance. Decis. Support Syst. 2014, 65, 69-79. [CrossRef]

46. Gao, Q.; Feng, C. Branding with social media: User gratifications, usage patterns, and brand message content strategies. Comput. Hum. Behav. 2016, 63, 868-890. [CrossRef]

47. Steers, R.M.; Porter, L.W. Motivation and Work Behaviour; McGraw-Hill: Singapore, 1991.

48. Berry, L.L. Relationship marketing of services-growing interest, emerging perspectives. J. Acad. Mark. Sci. 1995, 23, 236-245. [CrossRef]

49. Oliver, R.L. Attribute need fulfillment in product usage satisfaction. Psychol. Mark. 1995, 12, 1-17. [CrossRef]

50. Wu, J.; Huang, L.; Zhao, J.L.; Hua, Z. The deeper, the better? Effect of online brand community activity on customer purchase frequency. Inf. Manag. 2015, 52, 813-823. [CrossRef]

51. De Vries, L.; Gensler, S.; Leeflang, P.S. Popularity of brand posts on brand fan pages: An investigation of the effects of social media marketing. J. Interact. Mark. 2012, 26, 83-91. [CrossRef] 
52. Gensler, S.; Völckner, F.; Liu-Thompkins, Y.; Wiertz, C. Managing brands in the social media environment. J. Interact. Mark. 2013, 27, 242-256. [CrossRef]

53. Farmaki, A.; Olya, H.; Taheri, B. Unpacking the complex interactions among customers in online fan pages. J. Bus. Res. 2021, 125, 164-176. [CrossRef]

54. Ducoffe, R.H. How consumers assess the value of advertising. J. Curr. Issues Res. Advert. 1995, 17, 1-18. [CrossRef]

55. Deci, E.L.; Ryan, R.M.; Gagné, M.; Leone, D.R.; Usunov, J.; Kornazheva, B.P. Need satisfaction, motivation, and well-being in the work organizations of a former eastern bloc country: A cross-cultural study of self-determination. Pers. Soc. Psychol. Bull. 2001, 27, 930-942. [CrossRef]

56. Pai, P.; Arnott, D.C. User adoption of social networking sites: Eliciting uses and gratifications through a means-end approach. Comput. Hum. Behav. 2013, 29, 1039-1053. [CrossRef]

57. Altman, I.; Taylor, D. Social Penetration: The Development of Interpersonal Relationships; Holt, Rinehart and Winston: New York, NY, USA, 1973.

58. Patrick, H.; Knee, C.R.; Canevello, A.; Lonsbary, C. The role of need fulfillment in relationship functioning and well-being: A self-determination theory perspective. J. Pers. Soc. Psychol. 2007, 92, 434-457. [CrossRef]

59. Hudson, S.; Huang, L.; Roth, M.S.; Madden, T.J. The influence of social media interactions on consumer-brand relationships: A three-country study of brand perceptions and marketing behaviors. Int. J. Res. Mark. 2016, 33, 27-41. [CrossRef]

60. Yoo, C.W.; Sanders, G.L.; Moon, J. Exploring the effect of e-WOM participation on e-loyalty in e-commerce. Decis. Support Syst. 2013, 55, 669-678. [CrossRef]

61. Toker-Yildiz, K.; Trivedi, M.; Choi, J.; Chang, S.R. Social interactions and monetary incentives in driving consumer repeat behavior. J. Mark. Res. 2017, 54, 364-380. [CrossRef]

62. Reimer, T.; Benkenstein, M. Altruistic eWOM marketing: More than an alternative to monetary incentives. J. Retail. Consum. Serv. 2016, 31, 323-333. [CrossRef]

63. Jang, H.; Olfman, L.; Ko, I.; Koh, J.; Kim, K. The influence of on-line brand community characteristics on community commitment and brand loyalty. Int. J. Electron. Commer. 2008, 12, 57-80. [CrossRef]

64. Vafainia, S.; Breugelmans, E.; Bijmolt, T. Calling customers to take action: The impact of incentive and customer characteristics on direct mailing effectiveness. J. Interact. Mark. 2019, 45, 62-80. [CrossRef]

65. Dolan, R.; Conduit, J.; Fahy, J.; Goodman, S. Social media engagement behavior: A uses and gratifications perspective. J. Strateg. Mark. 2016, 24, 261-277. [CrossRef]

66. Prentice, C.; Wang, X.; Loureiro, S.M.C. The influence of brand experience and service quality on customer engagement. J. Retail. Consum. Serv. 2019, 50, 50-59. [CrossRef]

67. Yeh, Y.-S.; Li, Y.-M. Design-to-lure in the e-shopping environment: A landscape preference approach. Inf. Manag. 2014, 51, 995-1004. [CrossRef]

68. Wang, Y.; Ma, S.; Li, D. Customer participation in virtual brand communities: The self-construal perspective. Inf. Manag. 2015, 52, 577-587. [CrossRef]

69. Eisingerich, A.B.; Auh, S.; Merlo, O. Acta non verba? The role of customer participation and word of mouth in the relationship between service firms' customer satisfaction and sales performance. J. Serv. Res. 2014, 17, 40-53. [CrossRef]

70. Shih, H.P.; Lai, K.H.; Cheng, T.C.E. Informational and relational influences on electronic word of mouth: An empirical study of an online consumer discussion forum. Int. J. Electron. Commer. 2013, 17, 137-166. [CrossRef]

71. Laroche, M.; Habibi, M.R.; Richard, M.O.; Sankaranarayanan, R. The effects of social media based brand communities on brand community markers, value creation practices, brand trust, and brand loyalty. Comput. Hum. Behav. 2012, 28, 1755-1767. [CrossRef]

72. McGuire, W.J. Some internal psychological factors influencing consumer choice. J. Consum. Res. 1976, 2, 302-319. [CrossRef]

73. Statista. Facebook-Statistics \& Facts. 2021. Available online: https://www.statista.com/topics/751/facebook (accessed on 16 May 2021).

74. Lee, K.Y.; Choi, H. Predictors of electronic word-of-mouth behavior on social networking sites in the United States and Korea: Cultural and social relationship variables. Comput. Hum. Behav. 2019, 94, 9-18. [CrossRef]

75. Statista. Social Media Usage in South Korea-Statistics \& Facts. 2020. Available online: https://www.statista.com/topics/5274 / social-media-usage-in-south-korea/\#dossierSummary (accessed on 16 May 2021).

76. Fornell, C.; Larcker, D.F. Structural equation models with unobservable variables and measurement error: Algebra and statistics. J. Mark. Res. 1981, 18, 382-388. [CrossRef]

77. Hair, J.F.; Hult, G.T.M.; Ringle, C.M.; Sarstedt, M. A Primer on Partial Least Squares Structural Equation Modeling (PLS-SEM), 2nd ed.; Sage Publishing: Thousand Oaks, CA, USA, 2017.

78. Tabachnick, B.G.; Fidell, L.S. Using Multivariate Statistics, 3rd ed.; Harper Collins: New York, NY, USA, 1996.

79. Podsakoff, P.M.; Organ, D.W. Self-reports in organizational research: Problems and prospects. J. Manag. 1986, 12, 531-544. [CrossRef]

80. Swani, K.; Milne, G.R. Evaluating Facebook brand content popularity for service versus goods offerings. J. Bus. Res. 2017, 79, 123-133. [CrossRef]

81. Weaven, S.; Quach, S.; Thaichon, P.; Frazer, L.; Billot, K.; Grace, D. Surviving an economic downturn: Dynamic capabilities of SMEs. J. Bus. Res. 2021, 128, 109-123. [CrossRef] 
82. Scott, M.L.; Mende, M.; Bolton, L.E. Judging the book by its cover? How consumers decode conspicuous consumption cues in buyer-seller relationships. J. Mark. Res. 2013, 50, 334-347. [CrossRef]

83. You, Y.; He, Y.; Chen, Q.; Hu, M. The interplay between brand relationship norms and ease of sharing on electronic word-of-mouth and willingness to pay. Inf. Manag. 2021, 58, 103410. [CrossRef] 